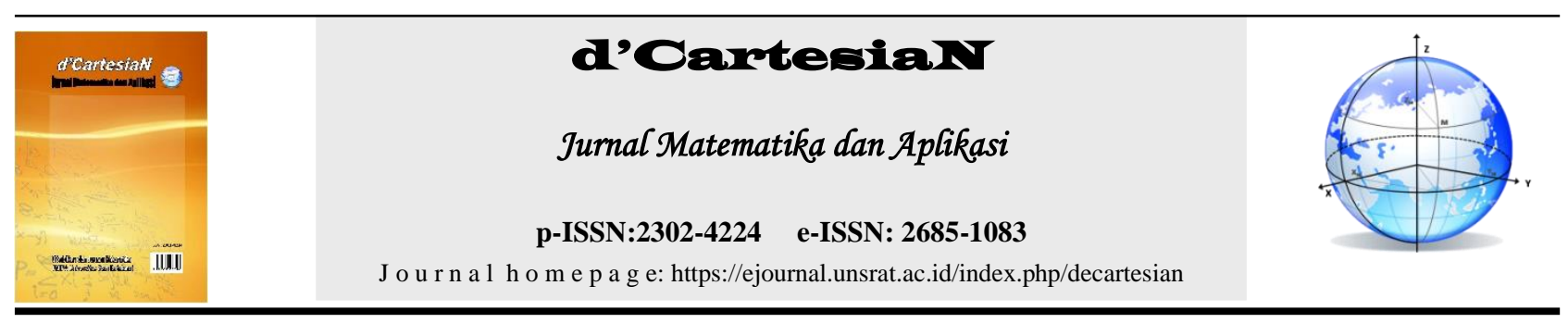

\title{
Analisis Volatilitas Harga Bawang Putih Di Kota Manado Menggunakan Model GARCH
}

\author{
Cesni Sinta kalengkongan ${ }^{1}$, Yohanes A.R. Langi ${ }^{1}$, Nelson Nainggolan ${ }^{{ }^{*}}$
}

${ }^{1}$ Jurusan Matematika-Fakultas Matematika dan Ilmu Pengetahuan Alam-Universitas Sam Ratulangi Manado, Indonesia

${ }^{*}$ Corressponding author : $\mathrm{n}$ nelson@unsrat.ac.id

\begin{abstract}
A B S T R A K
Analisis volatilitas harga sangat diperlukan oleh para pelaku ekonomi karena hasil analisisnya dapat digunakan untuk pengambilan keputusan terkait masalah resiko usaha. Salah satu metode untuk memodelkan perilaku data dengan volatilitas tinggi degan menggunakan model Generalized Autoregressive Conditional Heteroscedasticity (GARCH). Tujuan penelitian ini adalah menentukan volatilitas harga Bawang Putih menggunakan model GARCH. Data yang digunakan adalah data harga bulanan bawang putih periode Januari 2015 sampai Maret 2019. Hasil volatilitas harga bawang putih cenderung stabil pada Januari 2015 sampai Maret 2017 dan pada Juli 2018 sampai Februari 2019, sedangkan pada April 2017 sampai Juni 2018 volatilitas harga bawang putih berfluktuasi dengan amplitude yang lebih besar.
\end{abstract}

\section{INFO ARTIKEL}

Diterima : 16 Januari 2020

Diterima setelah revisi : 22

Januari 2020

Tersedia online : 25 Januari 2020

Kata Kunci:

GARCH

Volatilitas

Bawang Putih

\section{A B S T R A C T}

Analysis of price volatility is needed by economic actors because the results of the analysis can be used for decision making related to business risk issues. One method for modeling data behavior with high volatility using the Generalized Autoregressive Conditional Heteroscedasticity (GARCH) model. The purpose of this study is to determine the price volatility of Garlic using the GARCH model. The data used are the monthly price of garlic from January 2015 to March 2019. The results of the volatility of garlic prices tend to be stable in January 2015 to March 2017 and in July 2018 to February 2019, while in April 2017 to june 2018 the volatility of garlic prices

\section{ARTICLE INFO}

Accepted : 16 January 2020

Accepted after revision : 22

January 2020

Available online : 25 January 2020

\section{Keywords:}

GARCH

Volatility

Garlic

\section{PENDAHULUAN}

Dalam beberapa tahun terakhir, resiko dan ketidakpastian yang dihadapi oleh konsumen maupun produsen akibat fluktuasi harga bahan pokok cenderung meningkat. Naik turunnya harga bahan pokok (sembako) menunjukan besarnya volatilitas dan varian error. Varians dari residual bukan lagi hanya fungsi dari variabel independen tetapi juga selalu berubah-ubah, tergantung seberapa besar residual dimasa lalu [1].

Kenaikan harga bahan pokok berentetan dengan kenaikan harga barang dan biaya hidup akibat kenaikan harga BBM, seperti kenaikan tarif angkutan, dan lainnya sehingga terjadi gejala heteroskedastisitas pada data time series yang menunjukan unsur volatilitas [2].

Analisis volatilitas harga sangat diperlukan oleh para pelaku ekonomi karena hasil analisisnya dapat digunakan untuk pengambilan keputusan terkait masalah resiko usaha. Sebagaimana dikemukakan sebelumnya, harga komoditas pertanian mempunyai volatilitas yang sangat tinggi. Dampak yang timbul dari data yang volatilitas tinggi adalah peubah galat memiliki varians yang tidak konstan. Oleh karena itu, metode lain untuk memodelkan perilaku data dengan volatilitas tinggi dapat menggunakan model Autoregressive Conditional Heteroscedasticity (ARCH) [3].

Bawang putih sebenarnya berasal dari Asia Tengah, diantaranya Cina dan Jepang yang beriklim subtropik. Dari sini bawang putih menyebar ke seluruh Asia, Eropa, dan akhirnya ke seluruh dunia. Di Indonesia, bawang putih dibawa oleh pedagang Cina dan Arab, kemudian dibudidayakan di daerah pesisir atau daerah pantai. Seiring dengan berjalannya waktu kemudian masuk ke daerah pedalaman dan akhirnya bawang putih akrab dengan kehidupan masyarakat Indonesia. Peranannya sebagai bumbu penyedap masakan modern sampai sekarang tidak tergoyahkan oleh penyedap masakan buatan yang banyak kita temui di pasaran yang dikemas sedemikian menariknya [4].

Model Autoregressive Conditional Heteroscedastic (ARCH) diperkenalkan oleh [5] yang merupakan suatu model time series yang dapat mengakomodasi sifat heteroskedastik. Proses ARCH adalah proses dengan 
rataan (mean) nol, tak berkorelasi, variansi bersyarat (conditional) pada waktu lampau tidak konstan, sedangkan variansi tak bersyarat (unconditional) adalah konstan. Kemudian [6] mengembangkan model ARCH menjadi model Generalized Autoregressive conditional Heteroscedastic (GARCH) [6]. [5] telah berhasil melakukan penelitian tentang perkiraan varians dari inflasi Unitted Kingdom dengan menggunakan model Autoregressive Conditional Heteroscedastic (ARCH).

[7] menerapkan ARCH-GARCH untuk menganalisis volatilitas harga eceran komoditas beberapa pangan utama di Kota Manado dan [8] menerapkan model ARIMA-GARCH untuk memprediksi harga saham BNI dan BRI. Berdasarkan uraian diatas, maka dalam penelitian ini akan dilakukan pengujian pada harga Bawang Putih pada periode Januari 2015 sampai Maret 2019.

\section{Volatilitas Harga Komoditas Pertanian}

Volatilitas adalah besaran perubahan harga yang menunjukan fluktuasi pasar dalam satu periode waktu. Ukuran tersebut menunjukan penurunan dan peningkatan harga dalam periode pendek, tidak mengukur tingkat harga, namun derajat variasinya dari satu periode ke periode berikutnya. Perubahan ini dikarenakan penyesuaian pasar terhadap permintaan dan penawaran. Pada kasus harga komoditas pertanian, volatilitas terutama disebabkan dari gangguan sisi supply, sementara volatilitas pada industri terletak pada sisi demand [9].

\section{Kestasioneran}

Terdapat dua jenis kestasioneran, yaitu stasioner kuat dan stasioner lemah. Proses stokastik $\left\{Z_{t}\right\}$ dikatakan stasioner kuat (strickly stationary) jika distribusi gabungan dari $Z_{t 1}, Z_{t 2}, \ldots, Z_{t n}$ sama dengan distribusi gabungan dari $Z_{t 1-k}, Z_{t 2-k}, \ldots, Z_{t n-k}$, untuk semua $t_{1}, t_{2}, \ldots, t_{n}$ dan semua lag waktu $k$. Data yang tidak stasioner seringkali didapat dalam kehidupan nyata. Mengingat deret data yang digunakan dalam peramalan ARIMA adalah deret data yang variansi dan rata-ratanya telah stasioner maka untuk data yang tidak stasioner perlu dilakukan pembedaan (differencing) ataupun transformas [10].

\section{Fungsi Autokorelasi (ACF) dan PACF}

Dalam analisis deret waktu, fungsi autokovariansi, fungsi autokorelasi (ACF) dan fungsi autokorelasi parsial (PACF) merupakan hal penting untuk menentukan model dari data. Kegunaan dari ACF yaitu untuk menaksir parameter model MA dan PACF digunakan untuk menaksir parameter model AR. Koefisien autokorelasi (ACF) berarti korelasi deret berkala dengan deret berkala itu sendiri yang memiiki selisih waktu $k$ (lag- $k$ ).

Dalam time series stationer, autokorelasi parsial (PACF) di lag $k$ digunakan untuk mengukur tingkat keeratan antara $Z_{t}$ dan $Z_{t-k}$ setelah membuang pengaruh dari $Z_{t-1}, Z_{t-2, \ldots,}$ dan $Z_{t-k+1}$. Autokolerasi parsial membantu menetapkan model yang tepat untuk peramalan.

\section{White Noise}

Suatu contoh yang sangat penting dalam proses stasioner adalah proses yang dinamakan white noise, yang didefinisikan sebagai urutan dari variable acak yang independen (tidak saling bergantung) dan berdistribusi identic, disingkat dengan istilah i.i.d. Selanjutnya, [11] menjelaskan tentang proses white noise bahwa time series $\left\{\varepsilon_{t}\right\}$ dinamakan proses white noise apabila rangkaiannya marupakan variable acak yang independen dan berdistribusi identik, yang memenuhi:

$E\left(\varepsilon_{t}\right)=\mu_{\varepsilon}$ konstan (biasanya diasumsikan berharga nol) $\gamma_{k}=E\left(Z_{t}-\mu\right)\left(Z_{t+k}-\mu\right)=0$ untuk semua $k \neq 0$ $\gamma_{(0)}=\sigma^{2}$

\section{Model Autoregressive (AR)}

Model Autoregressive (AR) adalah model yang menyatakan bahwa nilai pengamatan sekarang tergantung pada nilai pengamatan pada waktu-waktu sebelumnya dari dirinya sendiri ditambah dengan white noise[10].

Proses Autoregressive orde- $p$ ditulis dengan $\operatorname{AR}(p)$ adalah berbentuk:

$$
Z_{t}=\phi_{1} Z_{t-1}+\phi_{2} Z_{t-2}+\cdots+\phi_{p} Z_{t-p}+\varepsilon_{t}
$$

\section{Model Moving Average (MA)}

Proses Moving Average (MA) adalah suatu proses linear yang hakikatnya hanya sejumlah berhingga, yaitu:

$$
Z_{t}=\varepsilon_{t}-\theta_{1} \varepsilon_{t-1}-\cdots-\theta_{q} \varepsilon_{t-q}
$$

Model seperti ini dinamakan model Moving Average orde- $q$, ditulis $\operatorname{MA}(q)$. Jadi proses Moving Average adalah model yang mana nilai $Z_{t}$ bergantung pada suku-suku white noise waktu sekarang dan waktu-waktu sebelumnya [10].

\section{Model ARMA (Autoregressive Moving Average)}

Model ARMA (Autoregressive Moving Average) adalah campuran dari model $\operatorname{AR}(p)$ dan $\operatorname{MA}(q)$, sehingga memiliki asumsi bahwa data periode sekarang dipengaruhi oleh data pada periode sebelumnya [12]. Persamaan model ARMA $(p, q)$ dapat ditulis

$$
\begin{gathered}
Z_{t}=\phi_{1} Z_{t-1}+\phi_{2} Z_{t-2}+\cdots+\phi_{p} Z_{t-p}+\varepsilon_{t}-\theta_{1} \varepsilon_{t-1}- \\
\theta_{2} \varepsilon_{t-2}-\cdots-\theta_{q} \varepsilon_{t-q}
\end{gathered}
$$

\section{Model ARIMA}

Model time series yang digunakan berdasarkan asumsi bahwa data time series tersebut stasioner artinya rata-rata dan varians suatu data time series konstan. Tapi seperti diketahui bahwa banyak data time series dalam ilmu ekonomi adalah tidak stasioner, jika data time series tidak stasioner maka metode yang digunakan untuk membuat data stasioner yaitu dilakukan dengan differencing untuk data yang tidak stasioner dalam varians [13]. Secara umum persamaan model ARIMA adalah sebagai berikut:

$$
\begin{aligned}
W_{t}= & \phi_{1} W_{t-1}+\phi_{2} W_{t-2}+\cdots+\phi_{p} W_{t-p}+\varepsilon_{t}-\varepsilon_{t}- \\
& \theta_{1} \varepsilon_{t-1}-\cdots-\theta_{q} \varepsilon_{t-q}
\end{aligned}
$$




\section{ANALISIS VOLATILITAS HARGA BAWANG PUTIH DI KOTA MANADO MENGGUNAKAN MODEL GARCH}

d'Cartesian: Jurnal Matematika dan Aplikasi, Vol. 9, No. 1, (Maret 2020): 43-49

\section{Heteroskedastik}

Secara umum permodelan time series univariat yang sering digunakan adalah model-model time series dari Box-Jenkins, yaitu model Autoregressive (AR), moving Average (MA), dan gabungan keduanya model Autoregressive Moving Average (ARMA). Tetapi dalam model tersebut asumsi yang digunakan untuk error adalah asumsi homoskedastik (variansi sama setiap waktu). Namun hal ini tidak cocok apabila berhubungan dengan data finansial, misalnya tingkat inflasi, harga saham, dan sebagainya [10].

Pada kenyataan di lapangan sering dijumpai data time series yang memiliki variansi error (suku gangguan) tidak konstan, diantaranya nilai rata-rata laju inflasi. Salah satu model time series yang mengizinkan adanya heteroskedastik variansi berubahubah untuk setiap waktu (t) adalah model autoregressive conditional hetoroscedastic (ARCH).

\section{Model ARCH-GARCH}

Volatilitas diestimasi dengan cara menghitung varians dan standar deviasi perubahan harga dengan jangka waktu tertentu yang menentukan seberapa cepat data berubah dengan keacakannya. Pemodelan data deret waktu umumnya dilakukan dengan menggunakan asumsi homoskedastisitas tidak bisa menjawab persoalan adanya volatilitas pada deret waktu ekonomi dan bisnis, karena umumnya data pada ekonomi dan bisnis mempunyai varians residual yang selalu berubah sepanjang waktu atau heteroskedastisitas. Model ARCH (Autoregressive Conditional Heteroscedasticity) adalah model yang memperhitungkan adanya unsur heteroskedastisitas dalam analisis deret waktu. Model ARCH pertama kali diperkenalkan oleh [5]. Model ARCH dipakai untuk memodelkan varians residual yang tergantung pada kuadrat residual pada periode sebelumnya (conditional) secara autoregresif (regresi diri sendiri). Model ARCH terdiri dari dua komponen varians yaitu varians yang konstan dan varians yang tergantung dari besarnya volatilitas pada periode sebelumnya. Jika volatilitas pada periode sebelumnya besar, maka varians pada saat ini juga akan besar. Varians tergantung dari varians pada masa lalu sehingga heteroskedastis dapat dimodelkan dan varians diperbolehkan untuk berubah antar waktu. Volatilitas yang besar di masa lalu dapat ditangkap dalam model ARCH [14]. Bentuk umum model ARCH (q) adalah :

$\sigma_{t}^{2}=\omega+\alpha_{1} \varepsilon_{t-1}^{2}+\alpha_{2} \varepsilon_{t-2}^{2}+\cdots+\alpha_{q} \varepsilon_{t-q}^{2}$

Kondisi yang sering kali terjadi adalah bahwa varians saat ini tergantung dari volatilitas beberapa periode dimasa lalu (conditional variance). Hal ini akan menyebabkan banyaknya parameter dalam conditional variance yang harus diestimasi. Pengestimasian parameter-parameter tersebut sulit dilakukan dengan presisi yang tepat. Oleh karena itu [6] memperkenalkan model GARCH (Generalized Autoregresssive Conditional Heteroschedasticity) yang merupakan pengembangan model ARCH. Model GARCH dikembangkan dengan mengintegrasikan autoregressi dari kuadrat residual lag kedua hingga lag tak hingga ke dalam bentuk varians pada lag pertama. Model ini dikembangkan sebagai generalisasi dari model volatilitas. Volatilitas berdasarkan model GARCH (p,q) mengasumsikan bahwa varians dari data fluktuasi dipengaruhi sejumlah $q$ data fluktuasi sebelumnya dan sejumlah $p$ data volatilitas sebelumnya [14]. Bentuk umum model GARCH (p,q) adalah :

$\sigma_{\mathrm{t}}^{2}=\omega+\beta_{1} \sigma_{\mathrm{t}-1}^{2}+\cdots+\beta_{\mathrm{p}} \sigma_{\mathrm{t}-\mathrm{p}}^{2}+\alpha_{1} \varepsilon_{\mathrm{t}-1}^{2}+\alpha_{2} \varepsilon_{\mathrm{t}-2}^{2}+\cdots+$

$$
\alpha_{\mathrm{q}} \varepsilon_{\mathrm{t}-\mathrm{q}}^{2}
$$

Pada model GARCH, varians terdiri dari tiga komponen. Komponen pertama varians yang konstan, komponen kedua adalah volatilitas pada periode sebelumnya (suku ARCH), dan komponen ketiga adalah varians pada periode sebelumnya (suku GARCH).

\section{METODE PENELITIAN Jenis Data}

Data yang digunakan dalam penelitian ini adalah data sekunder harga komoditas bawang putih yang diambil secara bulanan selama empat tahun yaitu dari Januari 2015 sampai Maret 2019.

\section{Sumber Data}

Sumber data dalam penelitian ini adalah data yang berasal dari Dinas Perindustrian Dan Perdagangan Daerah Provinsi Sulawesi Utara.

\section{Tahapan Prosedur Pendugaan Model ARCH- GARCH}

Adapun tahapan prosedur dalam penerapan model ARCH-GARCH adalah sebagai berikut:

1. Pengambilan Data

2. Plot Data

3. Periksa Kestasioneran

4. Identifikasi Model ARIMA

5. Estimasi Model ARIMA

6. Uji Diagnostik Model ARIMA

7. Identifikasi Efek ARCH-GARCH (Heteroskedastik)

8. Estimasi Model ARCH-GARCH

9. Perhitungan Nilai Volatilitas

\section{HASIL DAN PEMBAHASAN}

\section{Plot Data Perkembangan Harga Bawang Putih}

Berdasarkan plot data bulanan harga bawang putih di Kota Manado yang di analisis dari awal Januari 2015 sampai Maret 2019 terlihat bahwa harga berfluktuasi setiap bulannya. Harga bawang putih periode Januari 2015 sampai Maret 2019 dapat dilihat pada grafik yang disajikan pada gambar 1 :

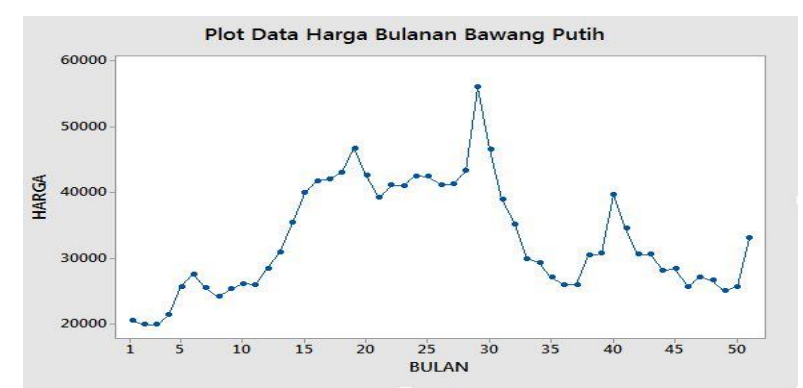

Gambar 1. Perkembangan Harga Bawang Putih Periode Januari 2015 sampai dengan Maret 2019 
Dari gambar 1 terlihat harga bulanan bawang putih berkisar antara Rp19.975,0o hingga Rp55.981,oo. Fluktuasi pola data menggambarkan adanya fluktuasi harga yang secara keseluruhan memiliki kecenderungan harga yang naik turun, harga terendah bawang putih adalah Rp19.975,00/kg yang dicapai pada bulan ke-3 , kemudian harga tertinggi bawang putih yaitu sebesar Rp55.981,00/kg yang dicapai pada bulan ke-29. Selanjutnya dari data bulan ke-29 menurun kembali dan cenderung berfluktuasi sampai data bulan ke-51 pada tahun 2019.

Setelah melihat harga plot dari data yang di analisis bahwa harga bawang putih cenderung naik turun atau tidak stabil dan akan dilanjutkan untuk menguji tingkat kestasioneran dari data.

\section{Uji Kestasioneran Data Uji Akar Unit (unit root test)}

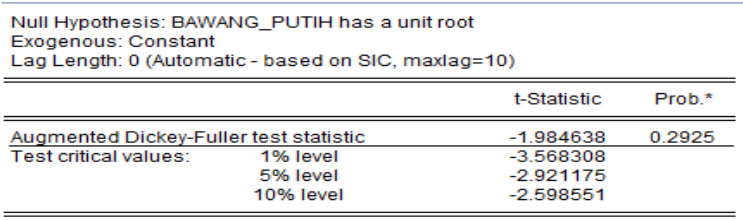

*MacKinnon (1996) one-sided p-values.

Gambar 2. Uji Akar Unit Harga Bawang Putih

Hasil uji akar unit dapat dilihat dari nilai $p$-value berdasarkan uji hipotesis sebagai berikut:

$\mathrm{H}_{0}$ : Bawang Putih memiliki akar unit (data tidak stasioner)

$\mathrm{H}_{1}$ : Bawang Putih tidak memiliki akar unit (data stasioner)

$\alpha: 0,05$

Jika nilai $p$-value $>0,05$ maka terima $\mathrm{H}_{0}$ atau harga bawang putih memiliki akar unit (data tidak stasioner), dan jika nilai $p$-value $<$ 0,05 maka tolak $\mathrm{H}_{0}$ atau harga bawang putih tidak memiliki akar unit (data stasioner). Selain melihat dari uji hipotesis, uji akar unit juga dapat dilihat berdasarkan nilai ADF (Augmented DickeyFuller). Jika nilai ADF> nilai Critical Value MacKinnon (1\% 5\% 10\%) maka terima $\mathrm{H}_{0}$ artinya harga bawang putih memiliki akar unit (data tidak stasioner), jika nilai $\mathrm{ADF}<$ nilai Critical Value MacKinnon (5\%) maka tolak $\mathrm{H}_{0}$ artinya harga bawang putih tidak memiliki akar unit (data stasioner).

\begin{tabular}{|c|c|c|}
\hline \multicolumn{3}{|c|}{$\begin{array}{l}\text { Null Hypothesis: D(BAWANG_PUTIH) has a unit root } \\
\text { Exogenous: Constant } \\
\text { Lag Length: o (Automatic- based on SIC, maxlag=10) }\end{array}$} \\
\hline & t-Statistic & Prob.* \\
\hline $\begin{array}{cc}\text { Augmented Dickey-Fuller test statistic } \\
\text { Test critical values: } & 1 \% \% \text { level } \\
5 \% \text { level } & 10 \% \text { level }\end{array}$ & $\begin{array}{l}-5.995556 \\
-3.571310 \\
-2.922449 \\
-2.599224\end{array}$ & 0.0000 \\
\hline
\end{tabular}

Gambar 3. Diferensing Uji Akar Unit Harga Bawang Putih

Dapat dilihat hasil output yang baru menunjukkan nilai $p$-value $(0,0000)<0,05$ dan nilai $\mathrm{ADF}(-$ 5,995556) < nilai Critical Value MacKinnon (5\%) maka tolak $\mathrm{H}_{0}$ artinya bawang putih tidak memiliki akar unit (data stasioner) [15].

\section{Correlogram ACF dan PACF}

Setelah melakukan uji akar unit dan diperoleh data sudah stasioner, maka selanjutnya kita dapat melihat dari correlogram ACF dan PACF.

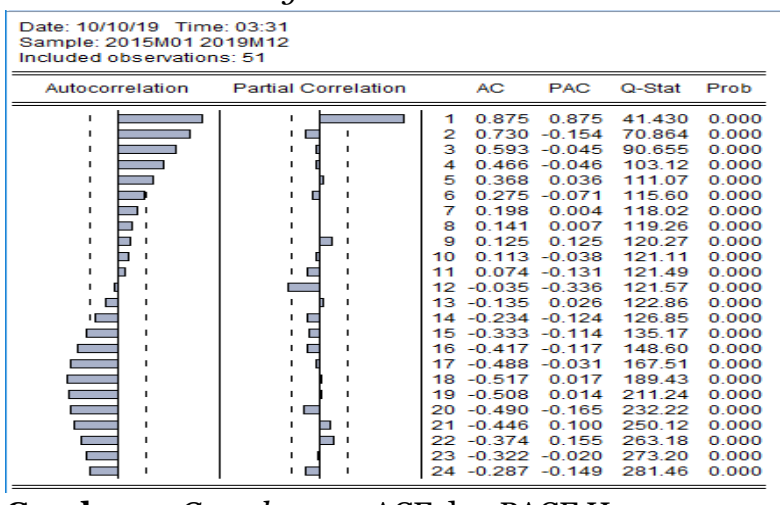

Gambar 4. Correlogram ACF dan PACF Harga Bawang Putih

Berdasarkan pada uji sebelumnya yaitu uji ADF telah diketahui bahwa data harga bawang putih sudah stasioner tetapi pada gambar 4 dapat dilihat grafik ACF menunjukkan penurunan secara perlahan dan grafik PACF juga menunjukkan penurunan secara drastis dari lag-1. Dari correlogram tersebut data harga bawang putih belum stasioner, maka data perlu dilakukan proses diferensing.

\section{Proses Diferensing}

Seperti yang telah kita ketahui bahwa data pada harga bawang putih menunjukkan data belum stasioner, maka perlu dilakukan proses diferensing. Berikut hasil correlogram ACF dan PACF diferensing satu:

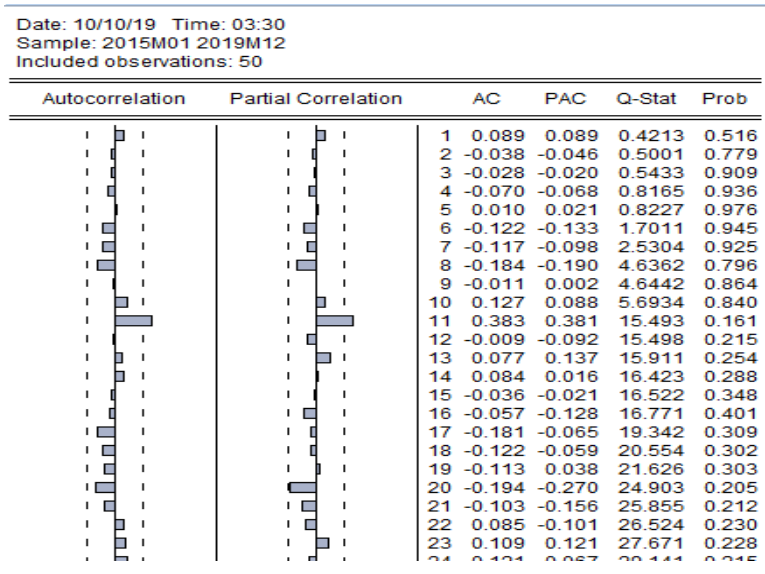

Gambar 5. Correlogram ACF dan PACF dif 1 Harga Bawang Putih

Berdasarkan pada gambar 5 menunjukkan nilai koefisien ACF sudah cukup rendah dan mendekati nol (o,089) pada lag-1 dan pada setiap lag nilai koefisien ACF relatif kecil, bahkan sampai pada lag-23 $(0,121)$. Pola nilai koefisien ACF dengan tingkat diferensing satu menunjukkan bahwa data sudah stasioner. 


\section{ANALISIS VOLATILITAS HARGA BAWANG PUTIH DI KOTA MANADO MENGGUNAKAN MODEL GARCH}

d'Cartesian: Jurnal Matematika dan Aplikasi, Vol. 9, No. 1, (Maret 2020): 43-49

\section{Identifikasi Model ARIMA}

Setelah mendeteksi masalah stasioner data selanjutnya identifikasi model ARIMA untuk data harga bawang putih. Dengan melihat correlogram ACF dan PACF. Sesuai dengan bentuk umum ARIMA (p,d,q) maka model ARIMA yang akan diestimasi yaitu sebagai berikut:

a. Model ARIMA dengan AR(1), tingkat diferensing satu d(1) dan tanpa MA(0) yaitu ARIMA $(1,1,0)$

b. Model ARIMA dengan tanpa memasukkan unsur AR atau AR (o), tingkat diferensing satu d(1) dan MA(1) yaitu ARIMA(0,1,1)

c. Model ARIMA dengan AR(1), tingkat diferensing satu d(1) dan MA(1) yaiu ARIMA (1,1,1)

\section{Estimasi Model ARIMA}

Setelah menetapkan model ARIMA maka kita dapat mengestimasi model tersebut, Hasil estimasi untuk masing-masing model ARIMA adalah sebagai berikut:

\section{a. $\operatorname{ARIMA}(1,1,0)$}

Berdasarkan identifikasi model, model ARIMA yang pertama yaitu ARIMA $(1,1,0)$ dapat dibentuk dalam persamaan sesuai dengan hasil estimasi pada output yaitu sebagai berikut:

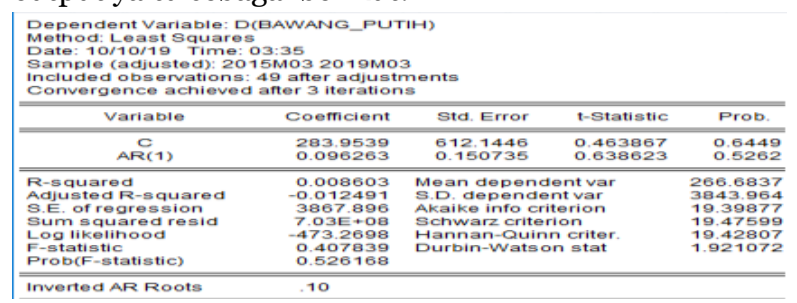

$$
\begin{gathered}
z_{t}-z_{t-1}=283,9539+0,096263\left(z_{t-1}-z_{t-2}\right)+\varepsilon_{t} \\
z_{t}=283,9539+z_{t-1}+0,096263 z_{t-1}-0,096263 z_{t-2} \\
\quad+\varepsilon_{t} \\
z_{t}=283,9539+1,096263 z_{t-1}-0,096263 z_{t-2}+\varepsilon_{t}
\end{gathered}
$$

\section{b. ARIMA $(0,1,1)$}

Berdasarkan identifikasi model, model ARIMA yang kedua yaitu ARIMA $(0,1,1)$ dapat dibentuk dalam persamaan sesuai dengan hasil estimasi pada output yaitu sebagai berikut:

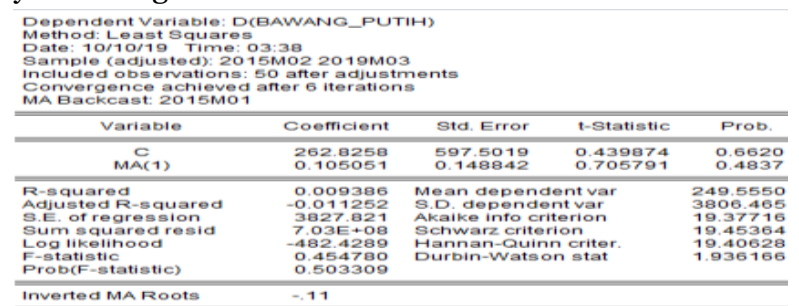

$z_{t}-z_{t-1}=262,8258+0,105051 \varepsilon_{t-1}+\varepsilon_{t}$

$z_{t}=262,8258+z_{t-1}+0,105051 \varepsilon_{t-1}+\varepsilon_{t}$

\section{c. ARIMA $(1,1,1)$}

Berdasarkan identifikasi model, model ARIMA yang ketiga yaitu ARIMA $(1,1,1)$ dapat dibentuk dalam persamaan sesuai dengan hasil estimasi pada output yaitu sebagai berikut:

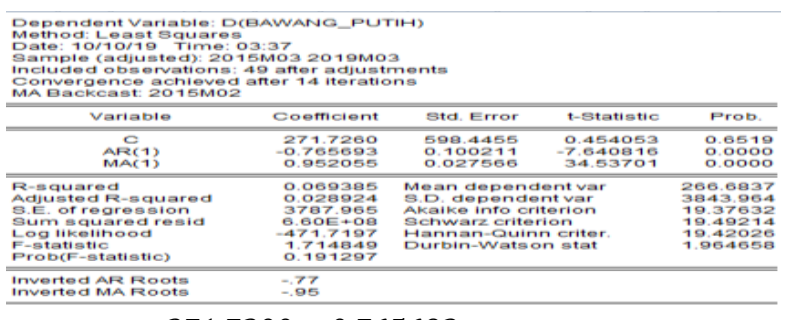

$z_{t}-z_{t-1}=271,7200-0,765693 z_{t-1}-z_{t-1}+$ $0,95255 \varepsilon_{t-1}+\varepsilon_{t}$

Tabel 1. Rekapitulasi SIC Masing-masing Model Harga Bawang Putih

\begin{tabular}{|c|c|}
\hline MODEL & SIC \\
\hline ARIMA $(1,1,0)$ & 19,47599 \\
\hline ARIMA $(1,1,1)$ & 19,49214 \\
\hline ARIMA $(0,1,1)$ & 19,45364 \\
\hline
\end{tabular}

Berdasarkan Tabel 1, statistik masing-masing model, kita dapat memilih model ARIMA yang terbaik. Dalam penelitian kali ini model terbaik yang akan dipilih dilihat berdasarkan nilai SIC yang paling terkecil. Hasil rekapitulasi pada tabel diatas menunjukkan masing-masing model, yang memiliki nilai SIC yang paling terkecil yaitu model ARIMA $(0,1,1)$ dimana nilai SIC sebesar 19,45364.

\section{Uji Diagnostik Model ARIMA}

Model ARIMA yang telah terpilih akan diuji apakah menghasilkan residual yang random (white noise) sehingga model tersebut merupakan model yang

\begin{tabular}{|c|c|c|c|c|c|}
\hline Autocorrelation & Partial Correlation & $\mathrm{AC}$ & PAC & a-Stat & Prob \\
\hline 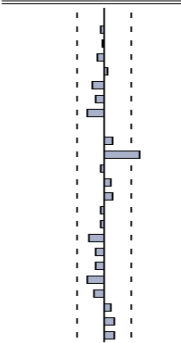 & 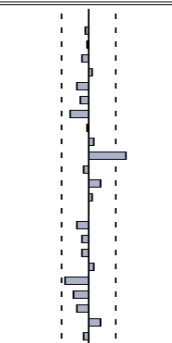 & $\begin{array}{ll}1 & -0.004 \\
2 & -0.035 \\
3 & -0.019 \\
3 & -0.071 \\
5 & 0.032 \\
6 & -0.119 \\
6 & -0.086 \\
3 & -0.178 \\
9 & -0.002 \\
10 & 0.084 \\
11 & 0.0373 \\
12 & -0.046 \\
13 & 0.073 \\
14 & 0.086 \\
15 & -0.041 \\
16 & -0.036 \\
17 & -0.069 \\
18 & -0.096 \\
19 & -0.090 \\
20 & -0.178 \\
21 & -0.100 \\
22 & 0.074 \\
23 & 0.103 \\
24 & 0.112\end{array}$ & $\begin{array}{l}-0.004 \\
-0.035 \\
-0.039 \\
-0.073 \\
0.030 \\
-0.125 \\
-0.089 \\
-0.199 \\
-0.019 \\
0.042 \\
0.048 \\
-0.065 \\
0.127 \\
0.034 \\
-0.005 \\
-0.126 \\
-0.070 \\
-0.074 \\
0.058 \\
-0.250 \\
-0.167 \\
-0.138 \\
0.124 \\
-0.051\end{array}$ & $\begin{array}{l}0.0008 \\
0.0680 \\
0.0971 \\
0.3748 \\
0.4326 \\
1.2695 \\
1.7171 \\
3.6723 \\
3.6725 \\
4.1304 \\
13.412 \\
13.555 \\
13.927 \\
14.455 \\
14.582 \\
14.682 \\
16.930 \\
17.673 \\
18.351 \\
21.112 \\
22.014 \\
22.525 \\
23.537 \\
24.793\end{array}$ & 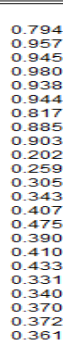 \\
\hline
\end{tabular}
baik yang mampu menjelaskan data dengan baik. Berikut adala correlogram ACF dan PACF white noise bawang putih:

Gambar 6. Correlogram ACF dan PACF white noise Harga Bawang Putih

\section{Identifikasi Efek ARCH-GARCH}

Dalam pemodelan GARCH didahului dengan identifikasi apakah data yang diamati mengandung heteroskedastik atau tidak. Untuk hasil ARCH-LM kita dapat mengambil keputusan berdasarkan uji hipotesis sebagai berikut:

$\mathrm{H}_{0}$ : Tidak ada efek ARCH-GARCH pada harga Bawang Putih (homoskedastik)

$\mathrm{H}_{1}$ : Ada efek ARCH-GARCH pada harga Bawang Putih (heteroskedastik) 
Jika nilai p-value $<0,05$ maka tolak $\mathrm{H}_{0}$ artinya ada efek GARCH (heteroskedastik), dan jika p-value > 0,05 maka terima $\mathrm{H}_{0}$ artinya tidak ada efek ARCH-GARCH (homokedastik).

Berikut merupakan hasil output uji ARCH-LM harga Bawang Putih

\begin{tabular}{|c|c|c|c|}
\hline \multicolumn{4}{|c|}{ Heteroskedasticity Test: ARCH } \\
\hline F-statistic & 14.18556 & Prob. F(1,47) & 0.0005 \\
\hline Obs*R-squared & 11.36040 & Prob. Chi-Square(1) & 0.0008 \\
\hline
\end{tabular}

Berdasarkan hasil uji ARCH-LM harga Bawang Putih menunjukkan bahwa nilai p-value < 0,05 yang artinya tolak $\mathrm{Ho}$ atau ada efek ARCH-GARCH (heterokedastik). Oleh karena itu, model ARIMA $(0,1,1)$ akan diestimasi model ARCH-GARCH karena memiliki unsur heteroskedastik.

\section{Estimasi Model GARCH}

Penerapan model GARCH dapat dilakukan dengan model yang telah diestimasi sebelumnya pada harga Bawang Putih yaitu ARIMA (0,1,1), yang dimana terdapat unsur heteroskedastik. Dalam menentukan model GARCH kita dapat me1ihat correlogram ACF dan PACF dari residual kuadrat, seperti pada output berikut:

\begin{tabular}{|c|c|c|c|c|c|c|}
\hline \multicolumn{7}{|c|}{$\begin{array}{l}\text { Date: } 10 / 10 / 19 \text { Time: } 03: 51 \\
\text { Sample: } 2015 \mathrm{MO} 22019 \mathrm{MOO} \\
\text { Included observations: } 50 \\
\text { Q-statistic probabilities adjusted for } 1 \text { ARMA term(s) }\end{array}$} \\
\hline Autocorrelation & Partial Correlation & & $\mathrm{AC}$ & PAC & Q-Stat & Prob \\
\hline 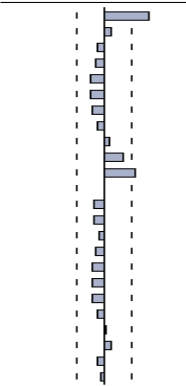 & 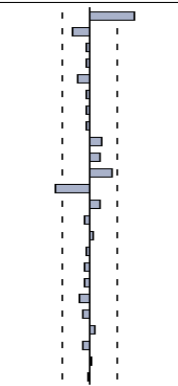 & $\begin{array}{r}1 \\
2 \\
3 \\
4 \\
5 \\
6 \\
7 \\
8 \\
9 \\
10 \\
11 \\
12 \\
13 \\
14 \\
15 \\
16 \\
17 \\
18 \\
19 \\
20 \\
21 \\
22 \\
23 \\
24\end{array}$ & $\begin{array}{r}0.473 \\
0.078 \\
-0.068 \\
-0.088 \\
-0.144 \\
-0.151 \\
-0.117 \\
-0.075 \\
0.064 \\
0.193 \\
0.331 \\
0.0066 \\
-0.102 \\
-0.102 \\
-0.054 \\
-0.087 \\
-0.117 \\
-0.121 \\
-0.134 \\
-0.076 \\
0.012 \\
0.070 \\
-0.067 \\
-0.033\end{array}$ & $\begin{array}{l}0.473 \\
-0.187 \\
-0.032 \\
-0.029 \\
-0.123 \\
-0.047 \\
-0.043 \\
-0.036 \\
0.122 \\
0.109 \\
0.224 \\
-0.355 \\
0.113 \\
-0.065 \\
0.033 \\
-0.035 \\
-0.063 \\
-0.061 \\
-0.112 \\
-0.076 \\
0.041 \\
-0.080 \\
0.018 \\
-0.016\end{array}$ & $\begin{array}{l}11.862 \\
12.195 \\
12.453 \\
12.893 \\
14.096 \\
15.448 \\
16.278 \\
16.628 \\
16.888 \\
19.308 \\
26.595 \\
26.598 \\
27.331 \\
28.084 \\
28.304 \\
28.886 \\
29.965 \\
31.154 \\
32.670 \\
33.165 \\
33.179 \\
33.632 \\
34.067 \\
34.175\end{array}$ & $\begin{array}{l}0.000 \\
0.0002 \\
0.005 \\
0.007 \\
0.009 \\
0.012 \\
0.020 \\
0.031 \\
0.023 \\
0.003 \\
0.005 \\
0.007 \\
0.009 \\
0.013 \\
0.017 \\
0.018 \\
0.019 \\
0.018 \\
0.023 \\
0.032 \\
0.0400 \\
0.048\end{array}$ \\
\hline
\end{tabular}

Gambar 7. Correlogram ACF dan PACF Residual Kuadrat Harga Bawang Putih

Berdasarkan gambar 7 correlogram ACF menunjukkan terjadi cuts off pada lag-1, kemudian pula dengan correlogram PACF menunjukkan terjadi cuts off pada lag-1. Sehingga dapat diduga model GARCH yang akan digunakan yaitu GARCH $(1,1)$. Berikut merupakan model GARCH $(1,1)$ :

\begin{tabular}{|c|c|c|c|c|}
\hline \multicolumn{5}{|c|}{ 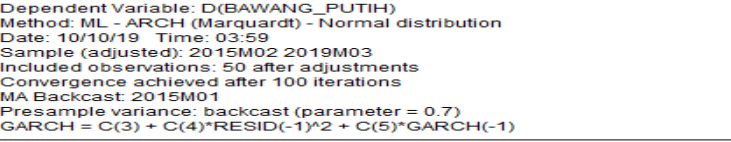 } \\
\hline Variable & Coefficient & Std. Error & $z$-Statistic & Prob. \\
\hline MA(1) & $\begin{array}{l}661.1872 \\
0.250680\end{array}$ & $\begin{array}{l}795.8896 \\
0.332144\end{array}$ & $\begin{array}{l}0.830752 \\
0.754733\end{array}$ & $\begin{array}{l}0.4061 \\
0.4504\end{array}$ \\
\hline \multicolumn{5}{|c|}{ Variance Equation } \\
\hline $\begin{array}{l}\mathrm{C} \\
\operatorname{RESID}(-1)^{m} 2 \\
\text { GARRCH(-1) }\end{array}$ & $\begin{array}{r}12123865 \\
0.292471 \\
-0.2275222 \\
\end{array}$ & $\begin{array}{r}10487285 \\
0.404861 \\
0.910083 \\
\end{array}$ & $\begin{array}{r}1.156054 \\
0.722398 \\
-0.25 .0001 \\
\end{array}$ & $\begin{array}{l}0.2477 \\
0.4700 \\
0.8026 \\
\end{array}$ \\
\hline $\begin{array}{l}\text { R-squared } \\
\text { Adjusted R-s quared } \\
\text { s. E. of regression } \\
\text { Sum squared resid } \\
\text { Log likelihood } \\
\text { Durbin-Watson stat }\end{array}$ & $\begin{array}{r}-0.016416 \\
-0.037591 \\
3.877 .350 \\
7.22 E+08 \\
-478.4091 \\
2.192041 \\
\end{array}$ & \multicolumn{2}{|c|}{$\begin{array}{l}\text { Mean dependent var } \\
\text { S.D. dependent var } \\
\text { Akaike info criterion } \\
\text { Schwarz criterion } \\
\text { Hannan-Quinn criter. }\end{array}$} & $\begin{array}{l}249.5550 \\
3806.465 \\
19.33636 \\
19.52756 \\
19.40917\end{array}$ \\
\hline Inverted MA Roots & -25 & & & \\
\hline
\end{tabular}

\section{Perhitungan Nilai Volatilitas}

Hasil analisis GARCH terhadap harga bawang putih menghasilkan model terbaik untuk estimasi volatilitas harga bawang putih yaitu model GARCH. Model tersebut memberikan informasi tentang tingkat pergerakan harga dari periode januari 2015 sampai Maret 2019. Persamaan harga Bawang Putih dituliskan sebagai berikut:

$$
\sigma_{t}^{2}=12123865+0,292471 \varepsilon_{t-1}^{2}-0,227522 \sigma_{t-1}^{2}
$$

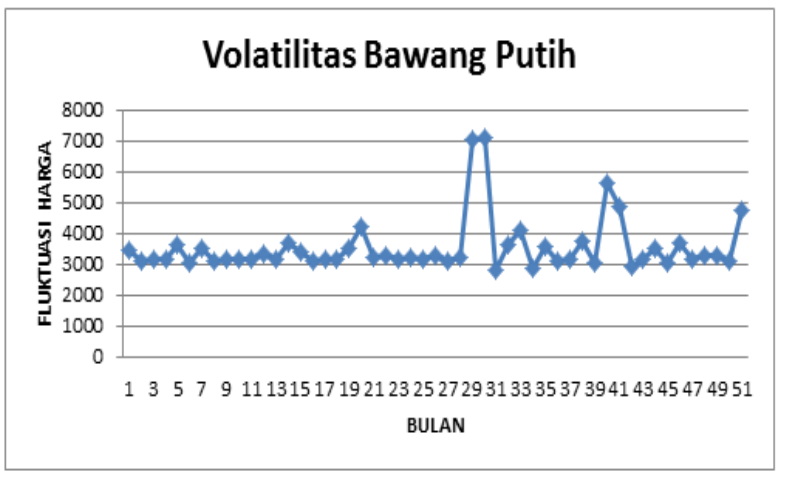

Gambar 8. Volatilitas Harga Bulanan Bawang Putih Periode Januari 2015 sampai Maret 2019.

Pada gambar 8, diperlihatkan volatiitas periode januari 2015 sampai maret 2019, 1-12 adalah tahun 2015, 3-24 adalah tahun 2016, 25-36 adalah tahun 2017, 37-48 adalah tahun 2018 dan 49-51 adalah 2019. Terlihat bahwa pada januari 2015 sampai maret 2017 dan pada Juli 2018-Februari 2019 volatilitas harganya cenderung stabil sedangkan pada bulan april 2017 Juni 2018 volatilitasnya berfluktuasi dengan amplitude yang lebih besar, artinya volatilitas harganya bergerak tidak stabil.

\section{PENUTUP \\ Kesimpulan}

Volatilitas harga periode januari 2015 sampai maret 2019, 1-12 adalah tahun 2015, 3-24 adalah tahun 2016, 25-36 adalah tahun 2017, 37-48 adalah tahun 2018 dan 49-51 adalah 2019. Terlihat bahwa pada januari 2015 sampai maret 2017 dan pada Juli 2018Februari 2019 volatilitas harganya cenderung stabil sedangkan pada bulan april 2017 Juni 2018 volatilitasnya berfluktuasi dengan amplitude yang lebih besar, artinya volatilitas harganya bergerak tidak stabil. Model GARCH terpilih untuk harga bawang putih adalah GARCH (1.1) yaitu :

$$
\sigma_{t}^{2}=12123865+0,292471 \varepsilon_{t-1}^{2}-0,227522 \sigma_{t-1}^{2}
$$

\section{REFERENSI}

[1] Widarjono. 2007. Ekonometrika: Teori dan Aplikasi untuk Ekonomi dan Bisnis. Ekonisia FE UI. Yogyakarta.

[2] Enders. 1995. Applied Econometric Time Series 2nd Edition, John Wiley \& sons, Inc. New York. 


\section{ANALISIS VOLATILITAS HARGA BAWANG PUTIH DI KOTA MANADO MENGGUNAKAN MODEL GARCH}

d'Cartesian: Jurnal Matematika dan Aplikasi, Vol. 9, No. 1, (Maret 2020): 43-49

[3] Engle, R.F.2004. Risk and Volatility : econometric models and financial practice. The American Ekono mi Review, 94:405-420.

[4] Syamsiah, I.S., dan Tajudin. 2003. Khasiat dan Manfaat Bawang Putih. Jakarta : Agromedia Pustaka.

[5] Engle, R.F. 1982. Autoregressive Conditional Heteroscedasticity with estimates of the Variance of United Kingdom Infatio. Journal of econometrica. 50:987-1008.

[6] Bollerslev, T. 1896. Generalized Autoregressive Conditional Heteroskedasticity. Journal of econometrics. 31:307-327.

[7] Nainggolan, W. N, Nainggolan, dan H. A. H. Komalig. 2018. Analisis Volatilitas Harga Eceran Komoditas Beberapa Pangan Utama Di Kota Manado Menggunakan Model ARCH-GARCH. Jurnal MIPA Unsrat Online. 7(2) 6-11.

[8] Natasya, B,Y. N, Nainggolan, dan H.A. H. Komalig. 2017. Penerapan Model ARIMA-GARCH Untuk Memprediksi Harga Saham BNI Dan BRI. Jurnal MIPA Unsrat Online. 6(2): 92-96.

[9] Firmansyah. 2006. Analisis Volatilitas Harga Kopi Internasional. Usahawan no. 07 Th XXXV.

[10] Nainggolan, N. 2009. Model Time Series Heteroskedastik. Unpad Press. Bandung.

[11] Wei, W.W.S. 1990. Time Series Analysis: Univariate and Multivariate Methods. AddisonWesley Publishing Company, USA.

[12] Nainggolan, N. 2011. Pengembangan Model GSTAR dengan Galat ARCH dan Penerapannya pada Inflasi. [disertasi] UNPAD, Bandung.

[13] Mulyana, 2004. Buku Ajar Analisis Deret Waktu. Universitas Padjajaran FMIPA Jurusan Statistika, Bandung.

[14] Wei, W. W. S. 2006. Time Series Analisys: Univariete and Multivariate Method. Addison Wesley Publishing Company, inc. USA.

[15] Tunang, Y. N, Nainggolan, dan Tohap, M. 2019. Penerapan Model Vector Autoregressive (VAR) Untuk Memprediksi Harga Cengkeh, Kopra dan Pala di Sulawesi Utara. d'cartesian : Jurnal Matematika dan Aplikasi, Vol. 8 No. 2 (September 2019): 100-107.

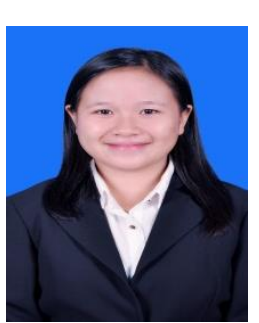

Cesni Sinta Kalengkongan

(Kalengkongancesni746@gmail.com) Lahir di Tempang, Sulawesi Utara pada tanggal 17 April 1997. Menempuh pendidikan tinggi Jurusan Matematika, FMIPA, Universitas Sam Ratulangi Manado. Tahun 2019 adalah tahun terakhir ia menempuh studi. Makalah ini merupakan hasil penelitian skripsinya yang dipublikasikan.

Yohanes A. R. Langi (yarlangi@gmail.com)

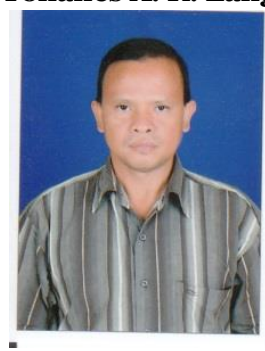

Lahir di Jakarta pada tanggal 13 Juni 1970. Pada tahun 1994 mendapatkan gelar Sarjana Sains (S.Si) yang diperoleh dari Universitas Kristen IndonesiaTomohon. Gelar Magister Sains diperoleh dari Institut Pertanian Bogor pada tahun 2007. Ia bekerja di UNSRAT di Program Studi Matematika sebagai pengajar akademik tetap UNSRAT.

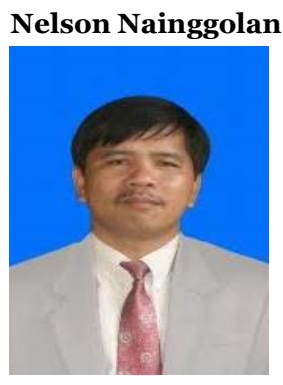

(n-nelson@unsrat.ac.id)

Lahir di Tapanuli Utara tanggal 9 Maret 1967. Gelar sarjana pendidikan Matematika diperoleh tahun 1992 di FMIPA IKIP Negeri Medan. Tahun 1996 menyelesaikan studi S2, di jurusan Matematika ITB Bandung. Tahun 2011 menyelesaikan studi S3 pada bidang Matematika di Universitas Padjadjaran Bandung. Saat ini menjadi pengajar akademik tetap di jurusan Matematika FMIPA Unsrat Manado. 